\title{
Department of History and International Studies
}

\author{
Olawale Lawal (PhD) \\ The Principle of Non-Refoulement in International law and Analysis of Prejudices \\ Lagos State University. Ojo
}

\begin{abstract}
The Principle of Non refoulement is the right granted by the 1951 Geneva Convention to refugees not to be returned to where they fear persecution having escaped to another state. This paper explains the importance of the this right to refugee movement across states' borders. this work takes cognizant of the restrictive intention of the principle whereas it is of utility also to wider international protection laws, nonspecific to refugees. The actual totem of this work is to establish a scope for the principle in a clear awareness that it has a customary law status and usefulness to all humans who deserve protection and not just refugees.
\end{abstract}

Key words. Refugee, Refugee Law, Non-Refoulement, Scope

\section{INTRODUCTION}

The principle of non-refoulement is seen as fundamental to refugee law. Since its expression in the Refugee Convention in 1951, it has played a key role in how states deal with refugees and asylum seekers. The principle is the idea that no refugee should be returned to any country where he or she is likely to face persecution or torture. Debate surrounds many aspects of this principle, including whether or not a refugee has to be found on the territory of a State or can merely be attempting to enter, and also what standard should be used to judge what danger warrants not returning the refugee (Lavenex, 1999: 2).

The massive refugee flows which followed the ructions of World War II provided an impetus for a thorough examination of the rules relating to refugees. Prior to this, there was general discontent which followed states failure to provide safe haven to refugees fleeing genocide under Nazi regime (Newmark, 1993: 11). In February, 1946, the United Nations accepted that refugees and displaced persons who had expressed 'valid objection' to returning to their country of origin should not be compelled to do so. This concern prompted largely by the huge number of refugees in Europe following the war eventually led to the drafting of the United Nations Convention relating to the status of refugee in 1951 (Newmark, 1993: 12). The principle of nonrefoulement is integrated in article 33 of the convention. Regional instruments represent a further set of protections of refugees particularly the 1969 Organization of African Unity Convention (for Africa) and the 1984 Cartagena refugee declaration (for Latin America). The Non-refoulement principle in fact is largely considered as "jus cogens" - customary international law, binding even on those states which have not embraced the 1951 UN Refugee Convention.

\section{SCOPE OF NON-REFOULEMENT}

The principle of non-refoulement has a fundamental 'judicial nature' (Hathaway 2005: 56). The principle talks about not returning refugees to where they fear persecution and torture. However in the event where a refugee has committed crime, should the principle still protect him from prosecution? The political nature of crimes being committed is practically eroding the efficacy of the principle of non-refoulement as it continued to come under attack by states or by individuals who by their acts have put the principle in harm's way. This observation has provoked literature in the areas of the exact scope of the principle, the difference between refoulement and extradition and the application of the principle to persecutory issues and its equidistance to events relating to prosecution.

Goodwin-Gill Guy (2004), in Overview of History and Scope of Non-refoulement And Current Attacks on the Principle maintains that in understanding the principle of non-refoulement attention should be paid to article 33 of the 1951 UN Convention on the status of Refugees which prescribes that:

(i) No contracting state shall expel or return (refoulement) a refugee in any manner whatsoever to the frontiers of territories where his life or freedom would be threatened on account of his race, religion, nationality, membership of a particular social group or political opinion.

(ii) The benefit of the present provision may not, however, be claimed by a refugee when there are reasonable grounds for regarding as a danger to the security of the country in which he is, or who, having been convicted by a final judgment of a particularly serious crime, constitutes a danger to the community of that country. 
This principle is later expressed in the various other refugee instruments:

- The 1996 Principles concerning Treatment of Refugees, Article FF(3) adopted by the Asian-African Legal Consultative Committee.

- The 1967 Declaration on Territorial Asylum, Article 3

- The 1969 Organization of African Unity Convention Governing the Specific Aspects of Refugee Protection in Africa, Article 11(3)

- The 1984 Cartegena Declaration Section 111, para 5.

Guy concludes that the Principle when viewed from refugee context should seek its scope from the provision establishing it. He maintains that article 33 of the UN Convention is the controlling provision from where all domestic and regional refugee conventions, should source the scope of the Principle of Nonrefoulement.Again Guy (2004) examines the Tension between Diplomatic Assurances and the Principle of Nonrefoulement in 'State Responsibility and the "Good Faith" Obligation in International Law'. He opened the discussion with the remark of Europe Commissioner for Human Rights, Alvaro Gil-Robles in July 2004 that:

The weakness inherent in the practice of diplomatic assurances lies in the fact that where there is a need for such assurances, there is clearly an acknowledged risk of torture or ill-treatment. Due to the absolute nature of the prohibition on torture or inhuman or degrading treatment, formal assurances cannot suffer where a risk nevertheless remains... when assessing the reliability of diplomatic assurances, an essential criteria must be that the receiving state does not practice or cordon torture or ill-treatment, and that it exercises effective control over the acts of non-state agents. In all other circumstances, it is highly questionable whether assurances can be regarded as providing indisputable safeguard against torture or ill-treatment.

These comments were inspired by the Swedish government's expulsion of two Egyptian asylumseekers in December 2001 on the strength of assurances from the Egyptian authorities. The men subsequently claimed to have been tortured.The issue of diplomatic assurances relate to states practice desirous of refoulement to seek assurances from refugees' own state that they will not be tortured or suffer ill-treatment if returned to them. Guy maintains that the efficacy of this practice is seriously undermining by the lack of substance which the entire gamut of diplomacy itself lacks - trust. He quotes from the 2000 April report of Human Rights Watch to prove his point:

Diplomacy entails the tactful management of foreign relations to promote the overall interest of the state. Human rights may be one of those interests, but it is seldom the only one, and as a consequence diplomacy cannot be an exclusive and reliable lever for human rights protection. The report cites the experience of the Swedish government in its expulsion in December 2001 of two Egyptians asylum-seekers. The Swedish ambassador was asked 'why five weeks were allowed to pass before he visited the men'. He replied that he could not have visited them immediately because that would have signaled a lack of trust in the Egyptian authorities.

The Convention Against Torture which investigated the case maintained that the Swedish government breached Article 3 of CAT and non-refoulement principle by returning the Egyptians in spite of the claim of diplomatic assurances from Egyptian authorities.The Committee maintained that:Cases must be decided in the light of the information that was known or ought to have been known, to the state party's authorities at the time of the removal. Subsequent event are relevant to the assessment of the state party's knowledge, actual or constructive at the time of removal. (Para 13:2)

The committee was of the view that "at the outset... it was known, or should have been known... to the Swedish authorities that Egypt resorted to consistent and widespread use of torture against detainees and the risk of such treatment was particularly high in the case of detainees held for political and security reasons.

Guy maintains that a lot of factors work against diplomatic assurances and that provide a basis to conclude that the principle of non-refoulement is still succinct to refugee protection. He maintains that a fundamental problem to diplomatic assurance is lack of trust. Seeking assurances from a state which has a record of torture and ill-treatment amounted to a state promising to give what she does not have. He maintains also that there should be post-return monitoring mechanism if diplomatic assurances become inevitable, but he said this monitoring is even not a guarantee since practice of torture and ill-treatment is extra-legal and usually convert. Guy maintains that Rogue State actors should not be trusted at all with diplomatic assurance as they would, most definitely breach their assurances. The issue of accountability is also raised by the author as he said monitoring arrangements are likely to be ineffective because they do not provide for a mechanism whereby accountability may be allocated. Human Rights Watch reports that typically the sending state will simply place blame on the recipient state for breach of the assurances. Other authors who have worked on the scope of principle of non refoulement are: Hathaway, James C. and Neve, R. Alexander (2005) in Making international refugee law relevant again: A proposal for collectivised and solution-oriented protection, Allain, J. (2001), in The Jus Cogen nature of non-refoulement', Howland, Todd (2007)in Refoulement of Refugees: the UNHCR's lost opportunity to ground temporary refuge in human rights law'Coleman, N. (2003). in Non-refoulement Revised: Renewed Review of the Status of the Principle of Non-refoulement as Customary International Law 
Crawford, J. \& Hyndman, P. (1989) in. Three heresies in the application of the refugee convention,,Kuruk, Paul in 'Asylum and the Non-refoulement of Refugees: The case of the missing shipload of Liberian refugees' Andrew Shacknove (1985) in "Who is a Refugee?" etc.

\section{NON-REFOULEMENT AND EXTRADITION}

Before the emergence of the principle of non-refoulement in international law, states heard only of their legal obligations to return individual to states which desire their return under international extradition law. Extradition in law is the surrender by one sovereign power to another, a fugitive from justice. The 1951 Convention also is silent completely about the extradition of refugees. This silence automatically exposes the extradition of refugee to the subjective interpretation of the limit of the principle of non-refoulement. This point is exacerbated by the fact that the political systems and penal codes of various states differ considerably, most nations have given definite expression in treaties to their mutual obligations regarding extradition. The general rule is that extraditable crimes must be those commonly recognized by civilized nations as malum in se (acts criminal by their very nature) and not mele malum prohibitum (acts made crimes by statute) and must be included in the extradition treaty. Authors have investigated the relationship between the principle of nonrefoulement and extradition law. The principle of non-refoulement in a breath appears to prejudice extradition. Guy (2003) alluded to the parameter dilemma betweennon-refoulement and extradition in 'Refugees and responsibility in the twenty-first century: More lessons from the South Pacific'. He opines that the 1951 Convention says nothing about the extradition of refugees. In principle, he maintains that non-refoulement should also apply in this context, for other provisions of the convention already recognized the interests of the state of refugee in not committing itself to the reception of serious criminals. Further, he explains that article 33(1) prohibits removal 'in any manner whatsoever'. The principle of non-refoulement according to Guy should not prejudice extradition once anyone suspected of a serious non-political crime would, in any event, be excluded from the benefit of the refugee status; but one suspected or guilty of a non-serious, non-political crime would remain liable to extradition, even to the state in which he or she had a well founded fear of persecution. In spite of their parallel, it is still possible for non-refoulement to give protection to political fugitives and the purpose of extradition is to prevent the successful escape from a state of any person who had been accused of crime. The author when examining this controversy writes about how the Executive Committee in 1980 examined extradition of refugees. The Committee recognized that refugees should be protected in regard to extradition to a country where they feared well founded reasons to fear persecution on the grounds enumerated in Article 1 (A) (2) of the 1951 Convention. Anxious to ensure not only the protection of refugees but also the prosecution and punishment of serious offences, the Executive Committee stressed 'that protection in regard to extradition applies to persons who fulfill the criteria of the refugee definition and who are not excluded by virtue of Article 1(F)(b) of the Convention.

The principle of non-refoulement should find relief in the statutory definition of a refugee since there are provisions for exclusion and cessation of refugee status on statutory grounds. Judicial decisions of states have come to seek relief from this premise whenever there appears to be conflict between non-refoulement and extradition. . Other scholarly interventions on the principle of non refoulement and extradition are Newmark, Robert L. (1993). Non-refoulement run afoul: The Questionable Legality of Extraterritorial Repatriation Programs, Weissbrodt, David and Hortreiter, Isabel (1999). The Principle of non-refoulement: Article 3 of the Convention against Torture and other Cruel, Inhuman or Degrading Treatment or Punishment in Comparison with the non-refoulement provisions of other international human rights treaties.

The 1951 Convention, the 1967 Protocol and the 1969 OAU Convention said nothing about extradition of refugees. This could be due to some underlying assumptions that refugees do not stand extradited or that one suspected of a serious non-political crime would be excluded from the benefit of refugee status. It is essential to point out that refugees too can commit political crime. The purview of extradition appears to be the political terrain and this observation suspect a clash between the principle of non-refoulement and extradition. The exclusion clauses in the international refugee instruments appears to have separated the two principles as paragraph 7(d) of the UNCHR Statute provides, that the competence of the High Commissioner shall not extend to a person:

in respect of whom there are serious reasons for considering that he/ or she has committed a crime covered by the procession of treaties of extradition or a crime mentioned in article VI of the 1945 London Charter of the International of the International Military Tribunal or by the provisions of article 14, paragraph 2, of the 1948 Universal Declaration of Human Rights.Article IF of the 1951 Convention states that the provisions of that Convention "shall not apply to any person with respect to whom there are serious reasons for considering" that:

(a) He or she has committed a crime against peace, a war crime, or a crime against humanity, as defined in the international instruments drawn up to make provision in respect of such crimes;

(b) $\mathrm{He} / \mathrm{she}$ has committed serious non-political crime outside the country of refuge prior to his/her admission to that country as a refugee; or 
(c) He/she has been guilty of acts contrary to the purposes and principles of the United Nations.

Article 5 of the OAU Convention replicates the language contained in Article IF of the 1951 Convention except for a reference to persons who have been "guilty of acts contrary to the purposes and principles of the Organization of African Unity". As the OAU Convention complements the 1951 Convention, the latter phrase should be read as subsumed within Article IF (c ) of the 1951 Convention, given the close connection between the OAU's and the UN's purposes. (Guy Goodwin-Gill, Jane McAdam 2007 : 324).

The observation here does not contain juridical details relating to grounds to apply the exclusion clauses, this is so to avoid legal semantic and substantive analysis of jurisprudence. The concern here is how refugee determination processes should address the alleged commission of crime by refugee claimants. Recent developments indicate that there is complicated interaction between the applicable convention and the provision of the principle of non-refoulement and the opportunities for creative interchange between refugee law and a system of international criminal law and transitional justice which, in the main, is the domain of extradition.

The most recent confrontation between extradition and the principle of non-refoulement took place between South Africa and Rwanda over Lieutenant - General Fautin Kayumsa Nyamwasa who is seeking asylum in South Africa. Nyamwasa held senior leadership position in the Rwandan Patriotic Front (RPF) and the Rwandan Patriotic Army (RPA), Nyamwasa was indicted in France and Spain for war crimes and crimes against humanity, plus a United Nation's report implicates him in human rights violations after the Rwandan genocide. Having accessed the refugee institution in South Africa Nyamwasa is constantly criticizing President Kagame of Rwanda. Rwanda now seeks extradition of Nyamwasa and pushes that he is held accountable for these crimes. There is a plain text to this development, namely Nyamwasa feared persecution under Kagame in Rwanda and therefore he qualifies clearly and categorically as a refugee, but he is also guilty of international crimes. (Fegley, Randall\& Arlin, 2010)

The extradition of refugees was examined in 1980 by the Executive Committee, which reaffirmed the fundamental character of the principle of non-refoulement, and recognized that refugee should be protected in regard to extradition to a country where they have well-founded reasons to fear persecution on grounds enumerated in Article 1(A) (2) of the 1951 Convention. Anxious to ensure not only the protection of refugees, but also the prosecution and punishment of serious offence, the Executive Committee stressed that protection in regard to extradition applies to persons who fulfill the criteria of the refugee definition and who are not excluded by virtue of Article 1(F)(b) of the Convention. (Goodwin-Gill. \& McAdam, J. 2007 : 404).

Attempts have been made by states to bring both extradition and non-refoulement principle to work together for the good of international refugee protection and for protection of international law. Under this arrangement, states are to accept a conditional extradition based on guarantees by the receiving state that the transfer will not constitute refoulement. This conditional extradition system is based on a number of assumptions, on plain text; it assumes that this arrangement will not lead to cessation of life through capital punishment. Again, it assumes that governments of states have the propensity to give guarantees and later return refugee claimants to refugee state after serving punishment for extraditable offences (UNHCR Notes). This practice however is found to be incompatible with the absolute nature of non-refoulement obligations. It has been observed again that while guarantees may be appropriate to ensure that individual will not be exposed to capital punishment, or an unfair trial, but that is not sufficient guarantee against torture and other inhuman treatment. This in itself is the core interest in international refugee protection and the centre-piece of non-refoulement obligations. (Fitzpatrick, $\mathrm{J}$ $.2000)$.

The principles of extradition and non-refoulement appear to be working on parallel lines and seeking cooperation between them should be perfectly in abeyance. As a matter of fact protection of refugees and the developments in refugee law suggest that the principle of non-refoulement is acting as Praetorian Guard against extradition of refugees.

\subsection{NON-REFOULEMENT AND EXPULSION}

While states may be bound by the principle of non-refoulement, they as yet retain discretion as regards both the grant of durable and the conditions under which it may be enjoyed or terminated. The 1951 Convention and the 1967 Protocol, however, have acknowledged that the expulsion of refugee raises special problems and under article 32, states parties undertake not to expel refugees lawfully in their territory save on grounds of national security or public order. Hathaway (2005)in Rights of Refugees and Henchkaerts (1995) in Mass Expulsion in Modern International Law and Practice have analyzed the relationship between non-refoulement and expulsion. Henchkaerts provides that the decisions to expel are further required to be in accordance with due process of law and except where compelling reasons of national security otherwise require, refugees shall be accorded the right of appeal. Moreover, refugees under order of expulsion are to be allowed a reasonable period within which to seek legal admission into another country, though, states retain discretion to apply such internal measures as they may deem necessary. Henchkaerts also talks about the restricted grounds of expulsion. He maintains that the benefit is limited to refugees who enjoy what might loosely be called "resident status" in the state in question, and one admitted temporarily remains liable to remain in the same way as any other alien.

DOI: 10.9790/0837-2206074857 $\quad$ www.iosrjournals.org $\quad 51 \mid$ Page


Hathaway in his analysis expresses deep concern that refugee protection is seriously jeopardized by expulsion of refugees leading to refoulement. He calls the attention of the Executive Committee to prevail on states to refrain from taking such measures and in particular from returning or expelling refugees contrary to the principle of non-refoulement. He maintains that one expelled for the serious reasons stated in article 32(1) is likely to face major difficulties in securing admission into any other country. Return to the country of origin being ruled out, the refugee may be exposed to prosecution and detention for failure to depart.

Cristiano d'Orsi (2008) discusses the principle of non-refoulement from the point of view of subSaharan Africa. The author looks at the relationship between expulsion and non-refoulement in his work SubSaharan Africa: Is a new special regional refugee law regime emerging? The author maintains that the traditional doctrine of international law allows every state to expel unwanted aliens, but he agrees that the doctrine simultaneously noted that political refugees often were constituted an exception. He explains that in the $20^{\text {th }}$ century, courts have indicated that genuine political refugees should not be deported to the prosecuting country. According to the author, in Africa, the rule of rejecting aliens seeking asylum is supported by the fact that states could refer to a sort of burden-sharing pillar of their continent's protecting refugees, which the 1969 OAU Convention maintains in Article II, paragraph 3. He maintains that many Sub-African countries including Nigeria, Benin, Lesotho, Senegal, South Africa and Swaziland also provide for the principle of non-refoulement in their respective national legislations. On that point, he maintains, doctrine seems to adopt a uniform approach. Orsi argues that in the national legislations of many Sub-Saharan African States the concepts of expulsion and refoulement are still being used interchangeably. According to him, the principle of non-refoulement prescribes that no refugee should be forced to return to any country where he or she is likely to face persecution. The authors agrees that refoulement is distinguishable from expulsion or deportation which are more formal processes whereby a lawfully resident foreigner may be asked to leave a state or may be removed against his or her will.

Orsi also attempts to explain why the principle of non-refoulement suffers constant breaches in SubSaharan Africa and in most part he concludes that countries are not obliged to adhere to non-refoulement because they are unable to meet refugee obligations due to financial reasons. At a conference organized by International Association of Refugee Law Judges in Abuja in November 2010, Kasim Balarabe in a presentation titled Removal of refugees: Expulsion, extradition and non-refoulement talks about Nigeria's commitment to the provisions of the 1951 Refugee Convention, 1967, the Refugee Protocol and the 1969 OAU Refugee Conventions. The presentation also addresses cases of expulsion and extradition in Nigeria. It is concluded that the two are not the same and not applicable to the principle of non-refoulement. The speaker maintains that the non-refoulement principle should not stand in the way of the Principle of expulsion and extradition as he said criminals may also disguise as refugees. The speaker cited instances where Nigeria had hosted refugees from Niger, Chad, Liberia and Sierra Leone without breaching the Principle of non-refoulement. He gave the fact that Nigeria was the only country in West Africa to allow a ship called "Bulk challenge" to berth in 1996 and thereby hosting the Liberian refugees. The paper however appears to have presented the non-refoulement principle from the point of view of prejudicing the principles of expulsion and extradition. The 1951 Convention however has excluded from the benefits of refugee status anyone suspected of a serious non-political crime. The conference however offered a relief when Geoff Gilbert, came to allay this concern when he came to deliver his paper on Exclusion from refugee Protection as he categorically stated that the non-refoulement should not stand in the way of criminals who should be prosecuted, he declared that non-refoulement is designed to prevent persecution and not prosecution which is the concern of expulsion and extradition.Sovereigns have the prerogative to regulate the presence of foreigners on their territories. This power is not unlimited as international human rights law places some restriction on the exercise of this power. The same international law enjoins state to grant the right to enter and leave a country at will to its citizens. In addition to general protection afforded to all foreigners, certain categories of foreigners are protected from removal. Refugees and certain class of migrants' workers enjoy the benefit of restriction of states on right of expulsion of aliens (Fritzpatrick, J 1999). As a preliminary remark, many terms are used in different states to refer to "expulsion"; some of them include "deportation", "removals", etc.A refugee who is lawfully in the territory of a state party is a beneficiary of non-refoulement principle as regards to the expulsion of refugees. Article 32 prohibits expulsion save on grounds of national security or public order. Article 32 also contains some procedural safeguards since it provides that decisions to expel are required to be in accordance with due process of law and except where compelling reasons of national security otherwise require, refugees shall be accorded the right of appeal. Again, refugees under order of expulsion are to be allowed, a reasonable period within which to seek legal admission into another country.The caveat on the right of non-refoulement in article 32 appears to have given the right of expulsion to states desirous of it especially since what constitute "compelling reason" of national security is to be measured internally by the applying state. States practices in Africa have shown that many states have regard for Article 32 more than Article 33 which prohibits removal. What sometimes is termed compelling reason of national security may be the expression of displeasure by state of origin of refugees. This expression can indeed be of national security concern for hosting states. This was the case during the Second World War when states 
expelled refugees on the demand of powerful leaders like Josef Stalin of Russia, Benito Mussolini of Italy and Adolf Hitler of Germany. There was palpable fear of military action amidst weak nations and even powerful nations in Europe tended to capitulate or unwilling to take military option over such "minor issue" of expulsion order. (Lambert, H. 2005 :47).

In Africa, especially during the internecine acrimony between the Hutu and Tutsi in East Africa, states engaged in a mutually destructive practice of expelling refugees to where they feared persecution and on the request of government of state which desired persecution (Okoth-Obbo, G. 2001). The principle of nonrefoulement appears seriously prejudiced by Article 32 of the refugee Convention of 1951 and Article 11(3) of the 1969 OAU Convention as regards expulsion. In contrast, the Convention Against Torture in its article 3 does not include any public security exception; every person is protected against expulsion to face torture, regardless of what he or she may have done in the past. In addition, according to article 3 of the Convention against Torture, the ill-treatment needs to be connected to one of the five grounds enumerated in the 1951 refugee definition (i.e. race, religion, nationality, membership of a particular social group or political opinion). On the other hand, since Article 1 of the Convention defines torture as committed by or with the consent of public authorities, a person must fear ill-treatment by public authorities in order to invoke the protection of Article 3.The expulsion of refugees has no doubt jeopardized the principle of non-refoulement, the thinking that a refugee stands expelled on the basis of national security also negates the total prohibition of refugees being sent to face persecution. In 2005, the Executive Committee general conclusions on International Protection expressed deep concern for refugee protection as states continued to take measures leading to refoulement. The Executive Committee further argued that since what constitute compelling reason of national security rests with the state authorities give states ground to negotiate themselves out of international protection obligations. It was also argued that a refugee who is expelled is irredeemably subject to persecution because he/she is likely to face major difficulties in securing admission into another country and since return to the country of origin being ruled out, the refugee may be exposed to prosecution and detention for failure to depart. The Committee recommended that expulsion should be employed only in very exceptional cases, but agreed that there are refugees delinquents, but it was suggested that they should be treated as national delinquents would be treated. More fundamental of the Committee recommendation on the principle of non-refoulement is the point that refugees can also be detained for reasons of national security or public order.African Commission on Human and Peoples' Rights has documented instances of expulsion of refugees but the expulsion of John K. Modise from Botswana provides a twist to the entire refugee convention and system (ACHP Report 1996-1997). The expulsion order handed down to Modise followed the fact that he was one of the founders of Botswana National Front Opposition Party. Modise presented himself as a citizen of Botswana, but he was born in South Africa when his father was working in South Africa. Botswana authorities regarded him as refugee from South Africa and thus expelled him to that country - a culmination of his political activities in Botswana. He however does not possess the national passport of South Africa. This is an interesting specter to the system of expulsion of refugee, namely the Bophuthatswana government wanted to expel her citizen to South Africa where he enjoys no nationality status. The African Commission on Human and Peoples' Rights observed in this case that states have obligation not to expose individuals to danger of torture or cruel, inhuman or degrading treatment or punishment by way of expulsion. The Committee further established that the prohibition of refoulement is unconditional in refugee convention and expulsion of citizens from his state is a violation of his human rights.

\section{Application Of The Non-Refoulement Principle}

The principle of non-refoulement is bugged by the duty and obligation which its provision hangs on states. The immediate reaction of state therefore is if admitting refugee would attract legal burden, then other aliens would be admitted without legal responsibility. Refugee law is for the protection of refugees but states can also use it to control refugees, this can be done if states have control over their borders. Chhangani (1992) in African refugee law: Problem and prospect maintains that the greatest challenge to refugee law in Nigeria is the porous border as he said there are 1,475 official borders and 1,975 unofficial boarders in Nigeria. He said the principle of non-refoulement has no meaning when government cannot even man adequately the officially recognized ones. The author maintains that there is no room for refoulement or expulsion when the boarders are not manned properly. This literature takes the discourse of the principle of non refoulement from the point of view of effectiveness of government in boarder management.

Olivia Bueno (2006) in his article Perspective on Refoulement in Africa examines the factors driving refoulement in Africa and general abuse of the principle of non-refoulement, by first analyzing the unique legal architecture in Africa - OAU Refugee Convention of 1969 relating to refugees. Second, the paper highlights three instances of refoulement in the continent and third, it uses the ground work laid by these examples to tease out some of the factors driving refoulement in Africa. The basic argument in the paper is around the failure of African government to integrate the non-refoulement norms in national legislations and to drive home these points, cases of refoulement are cited in Burundi, Tanzania and South Africa. The author could have 
investigated the reasons for this failure rather than presenting it as deliberate. There was also general nitpicking role of states' resources which the author assumes explain virtually all cases of refoulement in Africa.

Like Olivia Bueno, Wamba Frank (2007) in The principle of non-refoulement and Zambian legislation maintains that there are explicit provisions in the Control Act of Zambia upholding the refugees' right to protection from refoulement. On the contrary, Section 10 of the Control Act actually empowers the Minister of Internal Affairs to order the deportation of any refugee at any time. Furthermore, it authorizes courts to order the deportation of convicted refugees. The author who conducted research on the Angolan refugee population in Zambia maintains that in practice, the principle of non-refoulement has been undermined by the Department of Immigration's continuous application of the Immigration and Deportation Act Chapter 122 of the Law of Zambia to refugees and asylum seekers and consequently treats them as ordinary aliens and subject them to immigration-related charges such as illegal entry or presence in the country. The procedure applies has been that the Minister issues a declaration under Section 22(2) of the Immigration Act declaring a refugee a prohibited immigrant and thereby effectively circumvents the Principle of Non-refoulement.

These two works have largely contributed their quota to the structural deficiency of the Principle of Non-refoulement in national legislations of African States. All the countries mentioned in the works are signatories to the 1951 Refugee Conventions and 1967 Refugee Protocol and the OAU Refugee Convention 1969.The works also raise fundamental question as to whether the principle of non-refoulement is applicable to only international refugee laws, especially when it is a "lex specialize" (special law) or whether it is a part of the whole International Protection regime. This, in the main, is the concern of Jane McAdam (2007) in Complementary protection in international refugee law. In the book, a particular focus is paid to ways in which human rights law has extended states international protection obligations beyond the refugee convention widening the scope of non-refoulement to prevent states not only from removing refugees within the meaning of Article 1A (2) of the refugee conventions, but also other individual at risk of serious harm. The author argues further that some persons may fall outside the scope of the refugee convention but they risk ill-treatment that is very serious but does not amount to "persecution", or which is persecutory but not connected to one of the five convention grounds. The author observes that the most common basis for non-removal on human rights grounds is the prohibition of refoulement to torture or degrading treatment or punishment.

The main argument behind the author's view is that states tend to regard Refugee Convention rights as a status required by international law once a person has been formally recognized as a refugee. Conversely, the strong theoretical claims of universal human rights law do not always sit comfortable with the realities of state practices. The book claims that the non-refoulement principle enjoys the same legal status in international protection regimes as in the refugee convention.

Lambert H. (1999) in Protection Against Refoulement from Europe had earlier provided a vignette in support of non-refoulement for any human who needs it. The author's assumption is based on the fact that if the principle of non-refoulement is respected by states, then why it does matter whether its source is the refugee convention. According to the author:in the language of protection, it does not really matter whether protection against refoulement is provided under the Refugee Convention or under the principle of Human Rights Law, so long as it is effective p.56

The author argues further that if we ask who are the beneficiaries of international protection? we would discover that the refugees are just a part of an array of human beings who should benefit. He said being refugee should be regarded as only qualifying or constitutive of their status. McAdam and Lambert through these works have shown that the restrictive application of the non-refoulement principle to refugees is a restriction on the scope of international protection law.

Guy Godwin Jill and Jane McAdam (2007) in Refugee in international law, support the restrictive application of the principle of non-refoulement. The authors posit that the principle of non-refoulement, as it appears in Article 33 of the 1951 Convention, applies clearly and categorically to refugees within the meaning of Article 1. The book brings out the legal and to some extent, logical relationship between Article 33(1) on the principle of non-refoulement and article 1 on the definition of a refugee, by establishing that the entitlement to the protection of non-refoulement is conditioned simply upon satisfying the well-founded fear criterion. The writers however admit that there is a divergence between the words defining refugees' status and those requiring non-refoulement, because all those who require protection are not all refugees. This position clearly shows the influence of McAdam who had advocated elsewhere for wider application of the non-refoulement principle in international protection law.

Vladislava Stoyanwa (2002) in The principle of non-refoulement and the right of asylum seekers to enter state territory addressed the question whether asylum seekers are entitled to enter the territory of the state where they seek asylum and whether states are under obligation to provide asylum seekers access to their territory. The argument of the paper basically is that there cannot be protection from refoulement without access to state territory and in order to uphold the principle of refoulement a state has to conduct a fair and effective refugee status determination procedure which is possible only within the state's territory. This paper is written strictly in view of the 1951 Refugee Convention and the 1967 Protocol and its conclusion appears to have 
strengthened the non-refoulement principle but if subjected to Article II(3) of the OAU Refugee Convention of 1969 , it is undermining of the non-refoulement as the scope has been expanded to include prohibition of refoulement at the frontier of State. A critical survey of non-refoulement literature in Africa reveals that some refugees are removed even though the exclusion and the cessation clauses are not applicable to them. Vera Gowlland Debbas (June 2008) in Zimbabweans Seeking refuge in South Africa provides an exposition of the factors driving refoulement in South Africa. The work reveals the connection between the health of refugees and the health of non-refoulement principle. The work provides that as at December 2007 an estimated 1.7million out of 13million Zimbabweans are living with HIV and are in need of anti-retroviral treatment (ART). Since the facilities in Zimbabwe could only cater for 90,000 people living with HIV/AIDS (PLWHA), the rest are fleeing to neighboring countries especially South Africa. The author also posits that the 2007 global Tuberculosis control reports (TCR) from the World Health Organization (WHO) ranks Zimbabwe among the 22 countries with the highest tuberculosis burden in the world. The author also argues that there was high incidence of cholera in Harare and Bulawayo in the period, prompting the view that sick Zimbabweans are refugees seeking asylum in South Africa. Refoulement therefore was driven by the health hazard which these Zimbabwean refugees posed to the people of South Africa. The incidence of mass influx from Zimbabwe could have influenced the harsh and unbridled application of refoulement in South Africa. Iluyomade and Popoola (2001) inThe legal position of aliens in Nigerian law are of the opinion that African governments act more strongly in accordance with the principle of non-refoulement. The authors maintain that in both practice and jurisprudence, the Nigerian government has shown a historical acceptance of the principle of non-refoulement to the extent that asylum seekers are protected against rejection at the frontier and expulsion even when it is apparent that the applicants should be excluded from the advantage of the asylum according to the relevant provisions of the international conventions. The authors argued that Nigeria made no distinction between acceptable refugees and unacceptable refugees as other African countries. According to them, most African governments accepted refugees who are victims of colonial struggle and rejected those who are products of civil wars and strife in their home countries. The period for the later was put at 1960-1990 while the former was from 1990.

\section{Non-Refoulement And Customary International Law}

Recent developments (McAdam 2007; Lambert: 1995 and Bethlehem: 2006) in the study of the principle of non-refoulement have raised issues relating to the meaning and scope of the principle. Article 33 of the 1951 Refugee Convention restricted the use of the principle to refugees but the principle is gaining wider application in general human rights law. There is substantial evidence that the principle has now enjoyed the status of customary international law regardless of whether the issues at hand are related to refugee matters. In this context, special regard should be paid to the practice of international organizations, such as the UN General Assembly and the UNHCR that constantly endorse the principle of non-refoulement. The works of Lambert and Bethlehem have vigorously campaign for the wider application of the principle based on the prescription under human rights law. The general view expressed by these scholars is that a wider range of people should benefit from the principle of non-refoulement and that the principle should not be circumscribed around refugee status. They assert that non-refoulement has crystallized as a norm of customary international law in the following terms:

a) No person shall be rejected, returned, or expelled in any manner whatsoever where this would compel him or her to remain in or return to a territory where substantial grounds can be shown for believing that he or she would face a real risk of being subjected to torture or cruel, in human or degrading treatment or punishment. This principle allow for no limitation or exception.

b)In circumstances which do not come within the scope of meaning of refugee, no person seeking asylum maybe rejected, returned, or expelled in any manner whatever where this would compel him or her to remain in or to return to a territory where he or she may face a threat of persecution, or a threat to life, physical integrity or liberty (Lambert 1995).

The OAU Convention extends states protection responsibilities beyond article 1A (2) of the 1951 Convention to encompass flight from external aggression, occupation, foreign domination or events seriously disturbing public order in either part or whole of country of origin or nationality. This provision can also be viewed from the wider scope of non-refoulement on the assumption that they do not have to be refugees to enjoy international protection. Most Western writers e.g. Hathaway (2005) and Hailbronner (1986) have criticized the OAU refugee definition and the basis of acquiring refugee status in the regional convention, their disagreement is based on the optional character of nationalism which is the basis of refugee status of the OAU convention. While this view has been rejected by African scholars like Rutinwa (2006), the denial of refugee status base on OAU refugee definition does have some advantage for the wider application and customary international law status of the principle of non-refoulement. The sense here is that since the principle can also be applied to those who are not refugees, whatever is the rationale behind flight of the African refugees, they also deserve to benefit 
from the principle of non-refoulement. There are some scholars who do not agree with the view that the principle of non-refoulement should serve as a principle of customary international law. Hathaway (2005) for instance believes that the only human rights norm which has attained the status of customary international law is freedom from systemic racial discrimination. The general consensus however is that the principle has attained that status. It encompasses non-refoulement to persecution, based on Article 33 of the 1951 Convention and also to torture or cruel, inhuman or degrading treatment or punishment. This, in the main, is evidence of substantial development which the non-refoulement principle has undergone. It is no longer foremost international legal instrument relating to only refugees, but a number of treaties have imbibed it, the CAT for instance, appears to use the principle even more than in refugee doctrinaire. In one breath, the romance of the principle with other treaties seems to underscore its importance generally in international human rights. However, in another breadth, the principle is advertising itself as a vague morality based rule and essentially this serves to undermine its effectiveness. The principle's ubiquity in virtually all human rights treaties is gradually removing its borders which of course oust legal duties. In fact refugees now shop around to see which state has the most obliging refugee laws and in particular the widest interpretation of their non-refoulement obligations. This is a problem of differing definitions of non-refoulement in the various instruments. The principle of customary international law, has however provided a soft landing of some sort to the principle of nonrefoulement, thus providing the basis of its transplanting to other body of treaties to the extent that it finds expression in so many ways and in so many different instruments.

\section{NOTES}

[1]. Allain, J.(2001). 'The Jus cogens nature of non-refoulement'. 13 IJRL 533

[2]. Arboleda, E., (1991).Refugee definition in Africa and Latin America: The lessons of pragmatism,' 3 IJRL

[3]. Arboleda, E. \& Hoy, I., (1993). 'The Convention Refugee definition in the West: Disharmony of interpretation and application'. 5 IJRL 66

[4]. Bari, S. (1992). Refugee status determination under the Comprehension Plan of Action (CPA)', 4 IJRL 487.

[5]. Barutciski M.,(1998). Involuntary repatriation when refugee protection is no longer necessary: Moving forward after the 48th session of the Executive Committee', 10 IJRL .236.

[6]. Battjes, H.,(2006). .European asylum law and international law, Leiden: Martinus Nijhoff Publishers,

[7]. Bayefsky, A.F. \& Fitzpatrick, J. (Ed).(1992)...Human rights and forced displacement. The Hague: Martinus Nijhoff Publishers,

[8]. Brownlie, I.(2002). Basic documents in international law, Oxford: Oxford University Press, $5^{\text {th }}$ edn.,

[9]. Brownlie, I. .(2003). Principles of public international law, Oxford: Clarendon Press, $6^{\text {th }}$ edn.,

[10]. Brownlie, I. \& Goodwin-Gill, G. S.. (eds). (2006). Basic documents on human rights, Oxford: Oxford University Press, 5th edn.

[11]. Burgers, J. H., \& Danelius, H.(1988). The United Nations Convention against Torture: A handbook on the Convention against Torture and Other Cruel, inhuman or degrading treatment or punishment,.Dordrecht: Martinus Nijhoff Publishers.

[12]. Carlier, J.Y., Vanheule, D., Hullmann. K.. \& Pena Galiano, C.(eds).(1997).Who is a refugee? A comparative case law study, The Hague: Kluwer Law International,

[13]. Convention Against Torture (CAT)

[14]. Clapham A.(1993). Human rights in the private sphere: Oxford: oxford University Press,

[15]. Coleman, N.(2003). Non-refoulement revised: Renewed review of the status of the principle of nonrefoulement as customary international law', 5 European Journal of Migration and Law 23

[16]. Crawford, J. \& Hyndman, P. (1989). Three heresies in the application of the refugee convention', I 1 IJRL 152.

[17]. Cristiano d'Orsi (2008) Sub-Saharan Africa: Is a new special regional refugee Law regime emerging? Oxford University Press

[18]. Durieux, J.F. \& Hurwitz, A., (1999). How many is too many? African and European legal responses to mass influxes and refugees', 47 German Yearbook of International Law 105

[19]. Durieux, J.F. \& McAdam, J., (2004). Non-refoulement through time: The case for a derogation clause to the refugee convention in mass influx emergencies', 16 IJRL 4

[20]. Eggli, A. V.(2002).Mass refugee influx and the limits of public international law. The Hague: Martinus Nijhoff Publishers.

[21]. Feller, E., Turk, V., \& Nicholson, F.(,eds).(2003.) Refugee protection in international law: UNHCR's global consultations on international protection. Cambridge: Cambridge University Press.

[22]. Fritzpatrick, J., (2000). Temporary protection of refugees: Elements of a formalized regime. 94 AJIL 279

[23]. Fritzpatrick, J. (1999). The end of protection: Legal standards for cessation of refugee status and withdrawal of temporary protection. 13 Georgetown Immigration Law Journal 343 
[24]. Fritzpatrick, J., (1996). Revitalizing the 1951 Refugee Convention', 9 Harvard Human Rights Journal 229

[25]. Goodwin-Gill, G. (1978). International law and the movement of persons between states. Oxford: Clarendon Press.

[26]. Goodwin-Gill, G. S. (1989). Voluntary repatriation: Legal and policy issues', in Loescher \& Monahan, (eds). Refugees and International Relations, 255

[27]. Goodwill-Gill, G.S., (2000). Comment: Refugee Status and "Good Faith". 12 IJRL 663

[28]. Goodwin-Gill, G. S.,(2000). UNHCR and Internal displacement: Stepping into a legal and political minefield. in US Committee for Refugees, World Refugee Survey 2000, Washington, D.C., 26-31.

[29]. Goodwin-Gill, G. S. (2001). Note on paragraph 20 of General Assembly Resolution 55/74', 13 IJRL 255

[30]. Goodwin-Gill, G. S. (2003). Article 31 of the 1951 Convention relating to the Status of Refugees: Nonpenalization detention and in Feller, Turk, \& Ncholson (eds).Refugee Protection in International Law 185

[31]. Goodwin-Gill, G. S., (2003). Refugees and responsibility in the twenty-first century: More lessons from the South Pacific. 12 Pacific Rim Law \& Policy Journal 23

[32]. Goodwin-Gill, G. S. (2003). The individual refugee, the 1951 Convention and the Treaty of Amsterdam' in Guild, E. \& Harlow, C.(eds).Implementing Amsterdam: Immigration and Asylum Rights in EC Law, 141.

[33]. Goodwin-Gill, G.(2004).Overview of history and scope of non-refoulement and current attacks on the principle.Oxford: Hart Publishing, 120.

[34]. Goodwin-Gill, G. S.(2004). State responsibility and the "good faith" obligation in international law', in Fitzmaurice, M. \& Sarooshi, D.(eds).Issues of state responsibility before international judicial institutions, Oxford: Hart Publishing, 120.

[35]. Goodwin- Gill, G.S., (1989). The language of protection. I IJRL6

[36]. Goodwin-Gill, G. S. (28 June, 2005). Diplomatic assurances and deportationLondon:JUSTICE/Sweet \& Maxwell Conference on Counter-Terrorism and Human Rights,

[37]. Hathaway, J.,A. (2005). Reconsideration of the underlying premise of refugee law', 31 Harv. ILJ 129

[38]. Grahl-Madsen, A.. (1997).Commentary on the refugee convention 1951, 1962-63. Geneva: UNHCR.

[39]. Howland, Todd (2007). Refoulement of refugees: the UNHCR's lost opportunity to ground temporary refuge in human rights law. Refugees in International Law. Vol., 1

[40]. Iluyomade and Popoola (2001) The legal position of aliens in Nigerian law The Status of RefugeesInternational Law. Vol., 1

[41]. Lambert, H. (1999). Protection against refoulement from Europe. Dordrecht: Marrnus Nijhoff Publishers.

[42]. Matthew. Price, (2009) Rethinking asylum: History, purpose and limits.London: Stevens.

[43]. Melander, G. \& Nobel, P. (eds). (1978). African refugees and the law. Uppsala: Scandinavian Institute of African Studies,

[44]. Melander, G.,(1987). The two refugee definitions. Lund: Raoul Wallenberg Institute of Human Rights and Humanitarian Law, Report No. 4

[45]. Noll, G. (ed). (2005). Proof, evidentiary assessment and credibility in asylum procedures, Leiden: Martinus Nijhoff Publishers OAU/UNHCR, (1995).The Addis Ababa Symposium 1994. 7 IJLRSpecial Issue-Summer 1995

[46]. Okoth-Obbo, G.(2001).Thirty years on: A legal review of the 1969 OAU Refugee Convention Governing the Specific Aspects of Refugee Problems in Africa. 20 RSQ 79

[47]. Oloka-Onyango, J.(1994). The place and role of the OAU Bureau for Refugees in the African refugee crisis. 6 IJLR 34

[48]. Oloka-Onyango, J. (1991).Human rights, the OAU Convention and the refugee crisis in Africa', 3 IJLR 453

[49]. Sarooshi, D.(2005). International organizations and their exercise of sovereign powers. Oxford: Oxford University Press,

[50]. Shacknove, A (1985) ."Who is a Refugee?”95 Ethics 274, 277.

[51]. Sjoberg, T., (1991).The Powers and the persecuted: The refugee problem and the Inter-91990).

[52]. Viljoen F (2004). Introduction to the African Commission and regional human rights system' in Heyns C (ed) Human rights in Africa Vol.1 389-486.

[53]. Weis, P. (1979). The draft convention on territorial asylum. 50 BYIL 176

[54]. Weis, P.(1978).Review of Mutharika, the regulation of statelessness under international and national law: Texts and documents (1977). 72 AJIL 680

[55]. Weis, P.. The 1967 Protocol Relating to the Status of Refugees and Some Questions of the Law of treaties', 42 BYIL, 39 (1967). 